\title{
Isolation of bioactive compounds from medicinal plants used in traditional medicine: Rautandiol B, a potential lead compound against Plasmodium falciparum
}

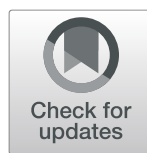

Christiana J. Dawurung ${ }^{1,2^{*}}$ D, Minh T. H. Nguyen ${ }^{3}$, Jutharat Pengon ${ }^{4}$, Kanchana Dokladda ${ }^{4}$, Ratchanu Bunyong ${ }^{4}$, Roonglawan Rattanajak ${ }^{4}$, Sumalee Kamchonwongpaisan ${ }^{4}$, Phuong T. M. Nguyen ${ }^{5}$ and Stephen G. Pyne ${ }^{1}$ (D)

\begin{abstract}
Background: Neorautanenia mitis, Hydnora abyssinica, and Senna surattensis are medicinal plants with a variety of traditional uses. In this study, we sought to isolate the bioactive compounds responsible for some of these activities, and to uncover their other potential medicinal properties.

Methods: The DCM and ethanol extracts of the roots of N. mitis and H. abyssinica, and the leaves of S. surattensis were prepared and their phytochemical components were isolated and purified using chromatographic methods. These extracts and their pure phytochemical components were evaluated in in-vitro models for their inhibitory activities against Plasmodium falciparum, Trypanosoma brucei rhodesiense, Mycobacterium tuberculosis, a-amylase $(A A)$, and a-glucosidase (AG).

Results: Rautandiol B had significant inhibitory activities against two strains of Plasmodium falciparum showing a high safety ratio (SR) and IC 50 values of $0.40 \pm 0.07 \mu \mathrm{M}(\mathrm{SR}-108)$ and $0.74 \pm 0.29 \mu \mathrm{M}$ (SR - 133) against TM4/8.2 and K1CB1, respectively. While (-)-2-isopentenyl-3-hydroxy-8-9-methylenedioxypterocarpan showed the highest inhibitory activity against $T$. brucei rhodesiense with an $I_{50}$ value of $4.87 \pm 0.49 \mu \mathrm{M}(\mathrm{SR}>5.83)$. All crude extracts showed inhibitory activities against AA and AG, with three of the most active phytochemical components; rautandiol $A$, catechin, and dolineon, having only modest activities against $A G$ with $I C_{50}$ values of $0.28 \mathrm{mM}, 0.36 \mathrm{mM}$ and $0.66 \mathrm{mM}$, respectively.

Conclusion: These studies have led to the identification of lead compounds with potential for future drug development, including Rautandiol B, as a potential lead compound against Plasmodium falciparum. The relatively higher inhibitory activities of the crude extracts against AG and AA over their isolated components could be due to the synergistic effects between their phytochemical components. These crude extracts could potentially serve as alternative inhibitors of $A G$ and $A A$ and as therapeutics for diabetes.
\end{abstract}

Keywords: Bioactivity, Phytochemicals, Traditional medicine, Crude extracts

\footnotetext{
* Correspondence: cjd910@uowmail.edu.au

'School of Chemistry and Molecular Bioscience, Faculty of Science Medicine and Health, University of Wollongong, Wollongong, NSW 2522, Australia

${ }^{2}$ Department of Veterinary Physiology, Biochemistry and Pharmacology University of Jos, Jos Plateau State, Nigeria

Full list of author information is available at the end of the article
}

(C) The Author(s). 2021 Open Access This article is licensed under a Creative Commons Attribution 4.0 International License, which permits use, sharing, adaptation, distribution and reproduction in any medium or format, as long as you give appropriate credit to the original author(s) and the source, provide a link to the Creative Commons licence, and indicate if changes were made. The images or other third party material in this article are included in the article's Creative Commons licence, unless indicated otherwise in a credit line to the material. If material is not included in the article's Creative Commons licence and your intended use is not permitted by statutory regulation or exceeds the permitted use, you will need to obtain permission directly from the copyright holder. To view a copy of this licence, visit http://creativecommons.org/licenses/by/4.0/. The Creative Commons Public Domain Dedication waiver (http://creativecommons.org/publicdomain/zero/1.0/) applies to the data made available in this article, unless otherwise stated in a credit line to the data. 


\section{Background}

Medicinal plants are useful in the treatment of many ailments and diseases among rural dwellers, indigenous users, traditional medicine (TM) practitioners, and livestock owners in many African countries. The traditional knowledge of medicinal plants if harnessed, can give insights into the vital role that medicinal plants play in drug development [1-3]. Often, a single medicinal plant can have multiple uses, and sometimes different parts of the same plant may be used for the treatment of more than one disease condition. Other times, the same plant could be used as an ingredient in herbal preparations for a synergistic effect $[1,4,5]$. This is made possible due to the range of phytochemicals that are present in medicinal plants along with their diversities of bioactivities. Neorautanenia mitis (A. Rich) Verdc. (Fabacae), Hydnora abyssinica A. Braun (Hydnoraceae), and Senna surattensis (Burm. f.) H. Irwin and Barneby (Fabaceae), were selected based on their promising preliminary screening results, they have shown various bioactivities and are traditionally used for the treatments of many disease conditions. The roots of N. mitis, are used for the treatment of bilharzia, syphilis, diarrhea, skin infection, dysmenorrhea and neuropsychiatric conditions. They are also used as an anticonvulsant, anti-malarial, fish poison, insecticide, and for killing bilharziascarrying fresh water snails in many African countries [6-10]. The crude extracts and phytochemical constituents isolated from $N$. mitis have shown antidiarrheal [3, 11], acaricidal, insecticidal [12], antinocicetive, antiinflammatory [9, 13], larvicidal, mosquitocidal [14], cytotoxicity $[11,15]$, and antimicrobial, activities [16]. $H$. abyssinica, is referred to as one of the strangest plants in the world, with its vegetative body consisting of only flowers, fruits and roots and has no leaves. It is not very common among botanists and plant scientists because it is rarely encountered [17-19]. However, it remains a popular and valuable medicinal plant among local users and TM practitioners, and is traded by traditional medicine vendors in local markets in South Africa, Mozambique and Nigeria [3, 19-23]. In some African countries including, Sudan, Kenya, South Africa, Malawi, Mozambique and Nigeria, it has been used for, the treatment of diarrhea, severe bacterial infections such as urinary tract infection, helminthiasis, internal wounds, piles, acne and dysentery, the expulsion of retained placenta and the treatment of throat and stomach aches [3, 17, 21, 24-27]. Extracts and constituents from H. abyssinica showed immunosuppressive [25], cytotoxic, antibacterial [17], antioxidant [28], molluscidal [29] and antidiarrheal activities [3].

$S$. surattensis is spread across tropical and subtropical countries, it is used as a food and as an ingredient in herbal mixtures. The roots are used for the treatment of gonorrhoea and snake bites, the leaves are used to treat dysentery and the flowers as a pugative [30, 31]. The crude extracts and phytochemical constituents from $S$. surattensis have shown antimicrobial [32, 33], antioxidant [33-35], antidiabetic [36, 37], antidiarrheal [3], hepatoprotective $[35,38]$, anthihyperlipidimic and antihyperglycemic activities [39].

In our continuous search for bioactive phytochemical constituents from medicinal plants, we evaluated the extracts and pure isolated phytochemicals from the three selected medicinal plants for their inhibitory activities against Plasmodium falciparum, Trypanosoma brucei rhodesiense, Mycobacterium tuberculosis, $\alpha$-amylase (AA) and $\alpha$-glucosidase (AG). These biological targets are associated with, malaria, human African trypanosome (HAT), tuberculosis and diabetes. The selections of these disease targets were based on the matching traditional uses of these plants and the need for newer drugs to aid in the combat against the growing drug resistance problems that are being encountered in the treatment of these conditions. Furthermore, malaria, HAT and tuberculosis are classified as re-emerging diseases [40, 41]. Malaria is a very important disease in Africa, it is caused by virulent Plasmodium falciparum which is transmitted through a bite of the female anopheles mosquito. It is endemic in most tropical countries of Asia, Africa and South America. A WHO report showed estimated deaths of 405,000 from 228 million infected cases in 2018 [42]. Malaria is both preventable and curable, and many anti-malaria drugs are available and control measures against the mosquito vector are also in place, however, resistance by the causative agent to each new class of drug has been reported, and this poses a grave challenge in combating this disease [43]. Therefore it is important to continue screening for new therapies and drug development leads, especially from alternative natural sources.

\section{Methods}

These experiments were set up to isolate and characterized compounds from the selected medicinal plants, their extracts and pure compounds were evaluated against $P$. falciparum, $T$. brucei rhodesiense, $M$. tuberculosis, $\alpha$-amylase (AA) and $\alpha$-glucosidase (AG) in in-vitro models.

\section{General experimental procedures}

The NMR data were recorded on Bruker Avance with Cryoprobe $(500 \mathrm{MHz})$ or Bruker Ascend $(400 \mathrm{MHz})$ NMR spectrometers in $\mathrm{d}_{4}$-methanol and deuterated chloroform $\left(\mathrm{CDCl}_{3}\right)$ with tetramethylsilane (TMS) as internal standard. The elucidation of all chemical structures was aided by IR, MS, NMR (1D and 2D), MP, and optical rotation. FTIR Shimadzu IRAffinity-1 with MIRacle was used to measure IR spectra. MS were measured 
on a LCMS-2020 Shimadzu for ESI, while HRSIMS were taken on Thermo Scientific Electron Transfer Dissociated (ETD) Orbitrap Fusion FSN 10314-1. A Buchi M.560 melting point apparatus and a Jasco P-2000 polarimeter were used to measure melting points and specific rotations, respectively.

\section{Collection and identification of plants}

All plants were collected from Kabwir Village in Kanke Local Government Area of Plateau State, Nigeria (Latitude $9^{\circ} 29^{\prime} 18.2^{\prime \prime} \mathrm{N}$ and $9^{\circ} 29^{\prime} 30.0^{\prime \prime}$ E) in July 2016. They were submitted for identification and authentication to the Department of Plant Science and Technology University of Jos, Nigeria where voucher/reference numbers were assigned as follows, $N$. mitis (UJ16000246), $S$. surattensis (UJ16000248), and $H$. abyssinica (UJ16000248) [3].

\section{Water extraction}

The aqueous extracts for this study were from the same batch of plant material as described in our previous study [3].

\section{Organic solvent extraction}

The roots of $N$. mitis, were chopped into small pieces and dried in an oven at $45^{\circ} \mathrm{C}$ for 2 days, while the leaves of $S$. surattensis were removed from the small stems and dried in a hot air oven at $45^{\circ} \mathrm{C}$ for 2 days. The roots of $H$. abyssinica were cut into small pieces and dried in a hot air oven at $45^{\circ} \mathrm{C}$ for 5 days. The dried plant materials were pulverized using a mortar and pestle. Measured amounts of the different plant materials $(N$. mitis$1000 \mathrm{~g}$, S. surattensis- $405 \mathrm{~g}$, H. abyssinica- $1000 \mathrm{~g}$ ) were successively extracted with DCM and ethanol using a ratio of 1:4 plant material:solvent, for $72 \mathrm{~h}$. The extracts were filtered through a sieve with a pore size of $150 \mu \mathrm{m}$, a cotton plug and then filter paper. Filtrates were evaporated and dried under a constant stream of air provided by a laboratory electric fan overnight, to obtain the dried crude DCM and ethanol extracts and their appearances and yields were recorded [44].

\section{Isolation of phytochemicals from S. surattensis}

The phytochemical components of the ethanol extract $(\mathrm{CEOH})$ from $S$. surattensis $(10 \mathrm{~g})$ were separated by flash column chromatography (CC) over silica gel with increasing gradient solvent polarity from $\mathrm{MeOH} / \mathrm{DCM}$ (1.5:85) to $100 \% \mathrm{MeOH}$. A total of 12 fractions were obtained (F1-F12). Fraction F2 (369.2 mg) was purified by CC over Sephadex (LH-20) by elution with $100 \% \mathrm{MeOH}$ to obtain 4 fractions (F2F1-F2F4). F2F3 was evaporated and identified as compound $\mathbf{1}(11.0 \mathrm{mg})$, while fraction F2F4 was identified as compound 2 (18.4 mg). Fractions F3-F4 $(524.5 \mathrm{mg})$ were combined and purified by CC over Sephadex (LH-20) by elution with $100 \% \mathrm{MeOH}$ to obtain 4 sub-fractions (F34f1-F34f4). Sub-fraction F34F3 (214 mg) was further purified by CC over Sephadex (LH$20)$ by elution with $100 \% \mathrm{MeOH}$ to obtain 9 subfractions (F34F3f1-F34F3f9). Sub-fractions F34F3f6F34F3f6 were combined and evaporated and identified as compound 3 (40.6 mg).

\section{Isolation of phytochemicals from $\mathrm{H}$. abyssinica}

About $50 \mathrm{~g}$ of the crude ethanol extract (KEOH) from $H$. abyssinica was partitioned with solvents from low polarity (hexanes) to high polarity ( $n$-butanol). The extract was dissolved in a mixture of distilled water and $\mathrm{MeOH}$ (10:90) and extracted with $200 \mathrm{~mL}$ of hexanes in a separating funnel and allowed to settle before the hexanes portion was collected. This process was repeated three times $(200 \mathrm{~mL} \times 3)$ to obtain the hexane extract $(4.7 \mathrm{~g})$ after evaporation of the volatiles under reduced pressure. In a similar way, the aqueous $\mathrm{MeOH}$ solution was then extracted with DCM (200 $\mathrm{mL} \times 3)$ to obtain the DCM extract $(8.70 \mathrm{~g})$. The same extraction procedure was repeated using ethyl acetate $(200 \mathrm{~mL} \times 3)$, acetone $(200 \mathrm{~mL} \times 3)$, and $n$-butanol $(200 \mathrm{ml} \times 3)$ in that order, to obtain the ethyl acetate $(833 \mathrm{mg})$, acetone $(3.9 \mathrm{~g})$ and $n$-butanol (1.8 g) extracts. About $2 \mathrm{~g}$ of the DCM extract was separated by $\mathrm{CC}$ over silica gel with $\mathrm{MeOH} / \mathrm{DCM}$ (10:90) as eluent to obtain 9 fractions (F1-F9). Fraction F5 was evaporated and identified as compound 3 (197 mg), and fraction F6 as compound $\mathbf{4}(45.8 \mathrm{mg})$.

\section{Isolation of phytochemicals from $N$. mitis}

A total of $14 \mathrm{~g}$ of the DCM crude extract (ABDCM) from $N$. mitis was separated by $\mathrm{CC}$ over silica gel using a gradient system from ethyl acetate (EtOAc)/hexanes (1:9) to $100 \%$ EtOAc to yield 40 fractions; these were combined based on their similarities by TLC and NMR analysis to afford 12 fractions (F1-F12). Compounds 524 were isolated through repeated CC, PTLC and CC over Sephadex LH-20 as previously described [11].

\section{Antimalaria assay against $P$. falciparum - TM4/8.2 and K1CB1}

Plasmodium falciparum TM4/8.2 and K1CB1 strains were maintained in RPMI 1640 medium supplemented with $8 \%$ human serum, $2.5 \mathrm{mM}$ HEPES and $2 \mathrm{~g} / \mathrm{L}$ sodium bicarbonate. Parasite cultures were incubated at $37^{\circ} \mathrm{C}$ in a $3 \% \mathrm{CO}_{2}$ incubator. The crude extracts/pure compounds were tested against TM4/8.2 and K1CB1 $P$. falciparum in vitro by the modified $\left[{ }^{3} \mathrm{H}\right]$ hypoxanthine incorporation assay $[45,46]$. Briefly, stock solutions of the crude extracts or pure compounds were prepared in DMSO. Various concentrations of the samples were incubated with malaria parasites with a final volume of 
$225 \mu \mathrm{L}, 1 \%$ parasitemia, $1.5 \%$ hematocrit, $0.1 \%$ dimethylsulfoxide (DMSO) in 96-well plates. Plates were incubated for $16-18 \mathrm{~h}$. Then, $25 \mu \mathrm{L} \quad\left[{ }^{3} \mathrm{H}\right]$-hypoxanthine solution was added and incubated for $20 \mathrm{~h}$. The parasites were harvested onto a UniFilter-96 GF/B plate (PerkinElmer, USA). The filters in the plates were air-dried, and then $25 \mu \mathrm{L}$ of liquid scintillation fluid (Microscint, Packard) was added. The radioactivity was then measured using a microplate scintillation counter (TopCount, Packard). The $\mathrm{IC}_{50}$ values of the crude extracts/ pure compounds were determined.

\section{Anti-trypanasomal assay ( $T$. brucei rhodesiense)}

T. brucei rhodesiense (STIB-900) was maintained in Minimal Essential Medium (MEM) with Earle's salts supplemented with $3 \mathrm{~g} / \mathrm{L}$ sodium bicarbonate, $4.5 \mathrm{~g} / \mathrm{L}$ glucose, $25 \mathrm{mM}$ HEPES, pH 7.3, $0.05 \mathrm{mM}$ bathocuproinedisulfonic acid disodium salt, $1.5 \mathrm{mM} \mathrm{L}$-cysteine, 1 $\mathrm{mM}$ hypoxanthine, $0.16 \mathrm{mM}$ thymidine, $1 \mathrm{mM}$ sodium pyruvate, $0.2 \mathrm{mM}$ 2-mercaptoethanol, $1 \%$ MEM nonessential amino acid, and 15\% heated fetal bovine serum, at $37{ }^{\circ} \mathrm{C}$ in a $5 \% \mathrm{CO}_{2}$ incubator. To assay anti-Tbr activity, a modified reported protocol was used [47, 48]. Briefly, $2 \times 10^{4}$ T. brucei rhodesiense parasites in $175 \mu \mathrm{L}$ culture media were incubated with $25 \mu \mathrm{L}$ of varying concentrations of each compound in a 96-well plate under the same culture conditions. Following $72 \mathrm{~h}$ incubation, $20 \mu \mathrm{L}$ Alamar Blue (a resazurin solution) was added in each well. The mixture was further incubated for $3 \mathrm{~h}$. The fluorescence signals were measured by a spectrofluorometer at ex $530 / \mathrm{em} 585 \mathrm{~nm}$. The results were read as concentration of each compound that exhibit 50\% growth inhibition $\left(\mathrm{IC}_{50}\right)$ from the dose-response curve established from the fluorescence signals at each concentration of compounds.

\section{Mycobacterium tuberculosis assay}

Mycobacterium tuberculosis H37Rv (ATCC 27294) were grown in Löwenstein-Jensen (LJ) medium agars (Biomedia Thailand cat. no. BMT B24420) in a biosafety level 3 facility at the Department of Microbiology, Faculty of Science, Mahidol University. Two-three loopfuls of each M. tuberculosis strain from the LJ medium were scratched and put into a tube containing $10 \mathrm{~mL}$ of Middlebrook $7 \mathrm{H} 9$ broth supplemented with $0.2 \%$ glycerol and $10 \%$ Middlebrook OADC. Clumps of colonies were dispersed using a loop. The bacterial suspensions were left undisturbed for $15 \mathrm{~min}$ before the upper parts were collected. Absorbance at $\mathrm{OD}_{600}$ was measured. Finally, bacterial suspensions were prepared to $\mathrm{OD}_{600}$ at 0.005 . Anti-tuberculous activities were evaluated by the Microplate Alamar Blue Assays [49]. The assay was performed in a 96-well microplate. From stock $10 \mathrm{mg} / \mathrm{mL}$ in dimethyl sulfoxide, two-fold serial dilution of compounds/ crude extracts $(0.312-20 \mu \mathrm{g} / \mathrm{mL})$ were prepared in Middlebrook $7 \mathrm{H} 9$ broth supplemented with $0.2 \%$ glycerol and $10 \%$ Middlebrook OADC in a 96-well plate to the volume of $100 \mu \mathrm{L}$. Then $100 \mu \mathrm{L}$ of $M$. tuberculosis $\left(\mathrm{OD}_{600}\right.$ of 0.005$)$ was added to each well. Bacterial growth control and compounds/crude extracts control wells contained the medium with either bacteria or the test sample, respectively, while the medium control wells were without both. All were done in triplicate. The plate was incubated in a $37^{\circ} \mathrm{C}$ incubator for 5 days. Then $20 \mu \mathrm{L}$ of alamar blue and $12.5 \mu \mathrm{L}$ of $20 \%$ Tween 80 were added to one well of each control and the plate was further incubated for $24 \mathrm{~h}$ to test bacterial growth by observing color change. A blue color in the well was interpreted as no bacterial growth while a pink color represented proper bacterial growth. Therefore, if the well was still blue, the additional control wells were tested daily until the color changed to pink. Then the reagents were added to the entire plate and incubated for $24 \mathrm{~h}$. Minimum inhibitory concentration (MIC) was then read from the lowest concentration of samples that prevented the change from blue to pink. Isoniazid and rifampin were employed as controls.

\section{Assay for a-glucosidase inhibition activity (AGI)}

AGI values of extracts and pure phytochemicals were quantitatively determined in a 96-well plastic plate according to the method described by Nguyen et al. [50]. The enzyme was incubated with the samples dissolved in DMSO for $5 \mathrm{~min}$ before adding the substrate. The inhibition was measured spectrophotometrically in $20 \mathrm{mM}$ sodium phosphate buffer $\mathrm{pH} 6.0$ at $37^{\circ} \mathrm{C}$ using $3.0 \mathrm{mM}$ $p$-nitrophenyl $\alpha$-D-glucopyranoside (Sigma) as the substrate and 0.25 units $/ \mathrm{mL}$ of AG from $S$. cerevisiae (Sigma). The absorbance at $405 \mathrm{~nm}$ was measured using a microplate reader (BioTek ELx808 microplate reader, USA). Acarbose $(5 \mathrm{mM})$ was used as the positive control.

\section{Assay for a-amylase inhibitory activity (AAI)}

AAI values were determined using a microplate-based starch-iodine assay. Assay reactions were initiated by adding $40 \mu \mathrm{L}$ of starch (Sigma S-2630) solution $(2.0 \mathrm{~g} / \mathrm{L}$ ) and $40 \mu \mathrm{L}$ of enzyme in $0.1 \mathrm{M}$ phosphate buffer at $\mathrm{pH}$ 7.0 to microplate wells. The enzyme was incubated with the samples for $5 \mathrm{~min}$ before adding the substrate. To minimize evaporative loss during incubation, a plastic mat was used to cover the microplate. After $30 \mathrm{~min}$ of incubation at $50{ }^{\circ} \mathrm{C}, 20 \mu \mathrm{L}$ of $1 \mathrm{M} \mathrm{HCl}$ was added to stop the enzymatic reaction, followed by the addition of $100 \mu \mathrm{L}$ of iodine reagent $\left(5 \mathrm{mM} \mathrm{I}_{2}\right.$ and $\left.5 \mathrm{mM} \mathrm{KI}\right)$. Following color development, the absorbance at $580 \mathrm{~nm}$ was measured using a microplate reader (Bio-TEK ELx808 microplate reader, USA) [51]. 


\section{Results}

The DCM and ethanol extracts from S. surratensis were coded from its species name 'cassia' as CDCM and $\mathrm{CEOH}$, respectively. While the DCM and ethanol extracts of $H$. abyssinica were coded from its local name 'kaushe' as KDCM and $\mathrm{KEOH}$, respectively. And the DCM and ethanol extracts from N. mitis were coded from its local name 'abargora' as ABDCM and ABEOH, respectively. The color and appearances and percentage yields of the DCM and ethanol extracts from all three plants are reported in Table 1, while that of the water extracts (S. surrattensis-CAQ, H. abyssinica-KAQ and $N$. mitis-ABAQ) were described earlier [3]. Higher percentage yields of 11.6 and $10.3 \%$ were observed from the ethanol extracts of $S$. surrattensis and $H$. abyssinica respectively, compared to their DCM extracts. However, the ethanol extract of $N$. mitis had a lower yield of $1.0 \%$ while its DCM yield was $1.5 \%$.

\section{Isolation of phytochemicals}

One extract from each plant, which were $\mathrm{CEOH}$ from $S$. surrattensis, $\mathrm{KEOH}$ from $H$. abyssinica and ABDCM from $N$. mitis, was selected for phytochemical studies which involved the isolation and structural characterisation of the pure chemical constituents. This selection was based on their promising preliminary biological activities and TLC profiles.

\section{Phytochemicals from CEOH and KEOH}

Three known compounds where isolated from $\mathrm{CEOH}$, they were; kempherol (1) [52], quercetin (2) [38], and (+)-catechin (3), which was also isolated from $\mathrm{KEOH}$ [53] together with salidroside (4) [54] (Fig. 1).

\section{Phytochemicals from ABDCM}

The phytochemical studies on ABDCM lead to the isolation of compounds 5-24 (Fig. 2), namely; neoduleen (5), neodulin (6), ferulic acid (7), ambonane (8), stigmasterole (9), pachyrrhizine (10), neotenone (11), 7-methoxy3-(6-methoxybenzo [d] [1,3] dioxol-5-yl) chroman-4-one (12), 12a-hydroxydolineon (13), dolineon (14), (-)-2-isopentenyl-3-hydroxy-8-9-methylenedioxypterocarpan

(15), nepseudin (16), neorautenol (17), isoneorautenol (18), (-)-2-hydroxypterocarpin (19), rotenone (20), 12a- hydroxyrotenone (21), dehydroneotenone (22), rautandiol A (23) and rautandiol B (24), as described previously [11].

Inhibitory activities of ABDCM and its compounds against Plasmodium falciparum, Trypanosoma brucei rhodesiense, and Mycobacterium tuberculosis

The ABDCM extract showed significant activity against two strains of $P$. falciparum giving $\mathrm{IC}_{50}$ values of $2.99 \pm$ $0.59 \mu \mathrm{g} / \mathrm{mL}(\mathrm{SR}-0.9)$ and $2.67 \pm 1.05 \mu \mathrm{g} / \mathrm{mL}$ (SR - 1.01) on TM4/8.2 and K1CB1, respectively. It also showed significant activity against $T$. brucei rhodesiense with an $\mathrm{IC}_{50}$ value of $3.04 \pm 0.27 \mu \mathrm{g} / \mathrm{mL}$. Compound $24 \mathrm{had}$ significant inhibitory activities against both strains of $P$. falciparum with $\mathrm{IC}_{50}$ values of $0.40 \pm 0.07 \mu \mathrm{M}$ (SR - 108) and $0.74 \pm 0.29 \mu \mathrm{M}$ (SR - 133) against TM4/8.2 and K1CB1, respectively. Compounds 11, 14, 15, 20, and 21 also showed inhibitory activity against $T$. brucei rhodesiense, with the highest activity displayed by compound 15 having an $\mathrm{IC}_{50}$ value of $4.87 \pm 0.49 \mu \mathrm{M}$ (SR > 5.83). $\mathrm{ABDCM}$ and its compounds were not active against $M$. tuberculosis (Table 2).

\section{Inhibitory activities of CEOH, KEOH and their compounds against Plasmodium falciparum, Trypanosoma brucei rhodesiense, and Mycobacterium tuberculosis}

The CEOH and KEOH extracts showed moderate activities against $T$. brucei rhodesiense with $\mathrm{IC}_{50}$ values of $18.14 \pm 1.34 \mu \mathrm{g} / \mathrm{mL}$ and $22.89 \pm 1.29 \mu \mathrm{g} / \mathrm{mL}$, respectively. Compounds 1 and 2, which were isolated from $\mathrm{CEOH}$, had significant inhibitory activities against $T$. brucei rhodesiense with $\mathrm{IC}_{50}$ values of $10.35 \pm 0.38 \mu \mathrm{M}$ (SR- 3.3) and $8.44 \pm 0.16 \mu \mathrm{M}$ (SR-4.52), respectively. None of the compounds from $\mathrm{KEOH}$ were active against $T$. brucei rhodesiense and neither the extracts nor the compounds isolated from $\mathrm{CEOH}$ or $\mathrm{KEOH}$ were active against $M$. tuberculosis (Table 2).

\section{Inhibitory activity of the crude extracts and their compounds against a-glucosidase and a- amylase} In this study, the crude extracts were screened for their AGI activities as shown in Fig. 3. The crude extracts from N. mitis (ABAQ, ABDCM and $\mathrm{ABEOH}$ ), S. surrattensis (CAQ, $\mathrm{CDCM}$ and $\mathrm{CEOH}$ ) and $H$. abyssinica

Table 1 Physical appearance and percentage yield of DCM and ethanol extracts from S. surratensis, H. abyssinica and N. mitis

\begin{tabular}{lllll}
\hline Extract & Colour/appearance & Dry plant material $(\mathbf{g})$ & Amount of extract $(\mathbf{g})$ & Percentage \\
\hline $\mathrm{CDCM}$ & Green solid & 405 & 11.0 & 2.7 \\
$\mathrm{CEOH}$ & Green sticky solid & 380 & 44.0 & 11.6 \\
$\mathrm{KDCM}$ & Brick red solid & 1000 & 10.0 & 1.0 \\
$\mathrm{KEOH}$ & Crystal like dark brown solid & 970 & 100.0 & 10.3 \\
$\mathrm{ABDCM}$ & Dark brown solid & 1000 & 15.0 & 1.5 \\
$\mathrm{ABOH}$ & Dark brown solid & 975 & 10.0 & 1.0 \\
\hline
\end{tabular}


<smiles>O=c1c(O)c(-c2ccc(O)cc2)oc2cc(O)cc(O)c12</smiles>

1

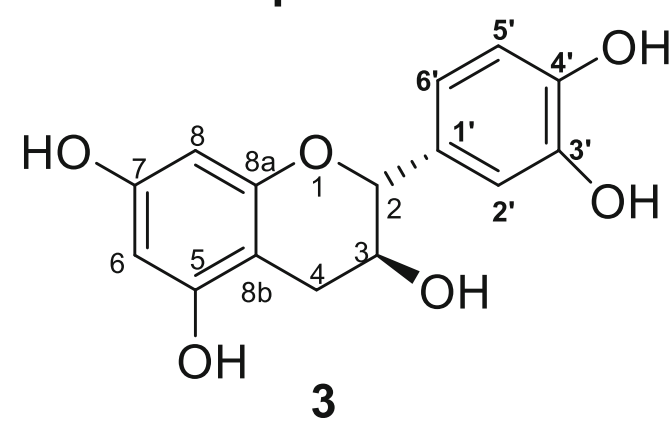<smiles>O=c1c(O)c(-c2ccc(O)c(O)c2)oc2cc(O)cc(O)c12</smiles>

2

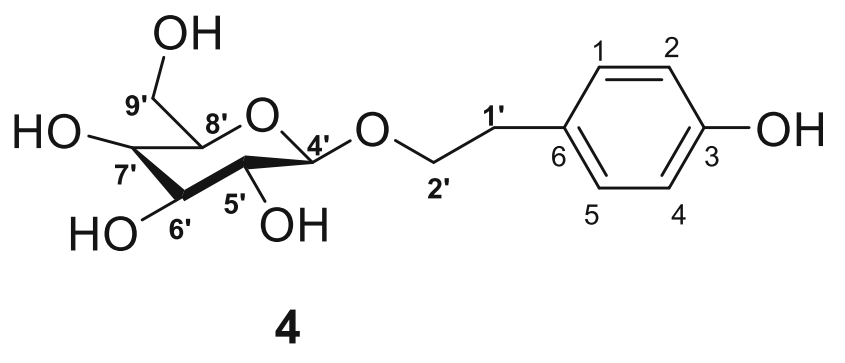

Fig. 1 Compounds isolated from $\mathrm{CEOH}(\mathbf{1}-\mathbf{3})$ and $\mathrm{KEOH}$ (3 and $\mathbf{4})$

(KAQ, KDCM and KEOH) show significantly higher percentage inhibitory activities than the positive control acarbose (71.3\%) except the aqueous extract (ABAQ) from $N$. mitis, which gave a lower inhibitory activity of $45.4 \%$. The highest inhibitory activity of $100 \%$ was from the DCM extract (ABDCM) from $N$. mitis.

The most active extracts were further analysed for their AAI and AGI activities. The data in Fig. 4 indicate that the ethanol crude extracts from $H$. abyssinica $(\mathrm{KEOH})$ had the highest inhibitory activity with $\mathrm{IC}_{50}$ values of $0.21 \pm 0.09 \mu \mathrm{g} / \mathrm{mL}$ against $\mathrm{AG}$ and $0.06 \pm 0.02$ $\mathrm{mg} / \mathrm{mL}$ against $\mathrm{AA}$. Both $\mathrm{IC}_{50}$ values were lower than that of acarbose which had $\mathrm{IC}_{50}$ values of $438.5 \pm 4.9 \mu \mathrm{g} /$ $\mathrm{mL}$ and $0.42 \pm 0.07 \mathrm{mg} / \mathrm{mL}$ for AG and AA, respectively.

$\mathrm{KAQ}$ had an $\mathrm{IC}_{50}$ value of $0.7 \pm 0.06 \mu \mathrm{g} / \mathrm{mL}$ and $0.31 \pm$ $0.01 \mathrm{mg} / \mathrm{mL}$ against $\mathrm{AG}$ and $\mathrm{AA}$, respectively. Also, the inhibitory activity of the DCM (ABDCM) and ethanol $(\mathrm{ABEOH})$ extracts of $N$. mitis against AG gave significant $\mathrm{IC}_{50}$ values of $26.8 \pm 1.01 \mu \mathrm{g} / \mathrm{mL}$ and $6.20 \pm 0.32 \mu \mathrm{g} /$ $\mathrm{mL}$, respectively.

Of the compounds screened at $250 \mu \mathrm{g} / \mathrm{mL}$ for their AG inhibitory activities, compounds 3, 14, and 23 showed significant percentage inhibitory activities of $97.5 \pm 0.6 \%, 54.2 \pm 8.9 \%$ and $83.9 \pm 1.0 \%$ when compared to the positive control acarbose that showed $86.5 \pm 0.4 \%$ inhibition (Table 3).

The $\mathrm{IC}_{50}$ values of these compounds were then determined against AG and AA (Table 4). Compound 3 (catechin) had modest $\mathrm{IC}_{50}$ values of $0.36 \mathrm{mM}$ and $2.26 \mathrm{mM}$ against AG and AA, respectively. Its inhibitory activity against AG was more than three times more potent than that of acarbose with an $\mathrm{IC}_{50}$ of $0.91 \mathrm{mM}$, however its potency against AA was three times less.

Compounds 14 and 23 from ABDCM also showed moderate inhibitory activities against $\mathrm{AG}$ with $\mathrm{IC}_{50}$ values of $0.66 \mathrm{mM}$ and $0.28 \mathrm{mM}$, respectively. Although the $\mathrm{IC}_{50}$ values of their inhibitory effect against AA were not determined, they may have played a role in the inhibitory activity displayed by the extract ABDCM.

\section{Discussion}

The higher percentage yields obtained from the ethanol extracts can relate to the fact that both polar and semipolar constituents of plant material can more readily dissolve in ethanol, leading to higher yields [55]. Previous phytochemical studies on S. surrattensis, collected from different locations, revealed the presence of quercetin, rutin, quercetin 3-O-glucoside 7-O- rhamnoside in the leaves [38], while 5,7-dihydroxy-4' -methoxyflavonol-3$O-\beta$-D-galactopyranoside, chrysophanol, physcion, kaempferide, quercetin were isolated from extracts of the pods [56]. The bark yielded, chrysophanol and physcion, [57] while 8-hydroxy-6-methoxy-3-methylanthraquinone-1-O- $\alpha$-L-rhamnopyranosyl $\quad(1-6)-\beta-\mathrm{D}$ glucopyranoside, chrysophanol, physcion, stearic acid, $\beta$ - 
<smiles>[R]c1cc2c(c([R])c1[R])O[C@@H]1C[C@@H]2COc2cc3occc3cc21</smiles>

5

6: $\mathrm{R}^{1}=\mathrm{H}, \mathrm{R}^{2}=\mathrm{R}^{3}=\mathrm{OCH}_{2} \mathrm{O}$

8: $R^{1}=R^{2}=O_{3}, R^{3}=H$<smiles>COc1cc2c(cc1-c1cc3cc4ccoc4cc3oc1=O)OCO2</smiles>

10<smiles>[R2][C@]12COc3cc4c(cc3[C@@]1([R7])C(=O)c1cc3ccoc3cc1O2)OCO4</smiles>

13: $\mathrm{R}^{1}=\mathrm{H}, \mathrm{R}^{2}=\mathrm{OH}$

14: $R^{1}=R^{2}=H$<smiles>CC1(C)C=Cc2cc3c(cc2O1)O[C@H]1c2ccc(O)cc2OC[C@@H]31</smiles>

18<smiles>COc1cc2c(cc1-c1coc3cc4occc4cc3c1=O)OCO2</smiles>

22<smiles>[R]c1cc(C2COc3cc4occc4cc3C2=O)c(OC)c([R])c1[R]</smiles>

11: $\mathrm{R}^{1}=\mathrm{R}^{2}=\mathrm{OCH}_{2} \mathrm{O}, \mathrm{R}^{3}=\mathrm{H}$

16: $R^{1}=H, R^{2}=R^{3}=\mathrm{OCH}_{3}$<smiles>CC(C)=CCc1cc2c(cc1O)OC[C@H]1c3cc4c(cc3O[C@H]21)OCO4</smiles>

15<smiles>COc1cc2c(cc1O)[C@@H]1Oc3cc4c(cc3[C@@H]1CO2)OCO4</smiles>

19<smiles>CC1(C)Oc2cc3c(cc2C[C@@H]1O)[C@H]1Oc2cc(O)ccc2[C@H]1CO3</smiles>

23<smiles>COc1ccc2c(c1)OCC(c1cc3c(cc1OC)OCO3)C2=O</smiles>

12<smiles>CC1(C)C=Cc2cc3c(cc2O1)OC[C@H]1c2ccc(O)cc2O[C@H]31</smiles><smiles>[R]C12COc3cc(OC)c(OC)cc3[C@@]1([R])C(=O)c1ccc3c(c1O2)C[C@@H](C)O3</smiles>

20: $\mathrm{R}^{1}=\mathrm{R}^{2}=\mathrm{H}$

21: $R^{1}=O H, R^{2}=H$<smiles>[Z4][C@H]1Oc2cc(O)ccc2[C@@H]2COc3cc4c(cc3[C@@H]12)C[C@@H](C(C)(C)O)O4</smiles>

Fig. 2 Compounds isolated from ABDCM (5-24)

sitosterol and $\beta$-sitosterol- $\beta$-D-glucoside were isolated from the stem $[58,59]$. The seeds yielded luteolin-7-O$\beta$-D-glucopyranosyl-(1-4)-O- $\alpha$-L-arabinopyranoside, $\gamma$ sitosterolin and digitolutein $[60,61]$. Our studies shows that compounds $\mathbf{1}$ and $\mathbf{3}$ were isolated from this plant for the first time, the differences in the chemical constituents from the different parts of this plant may account for the variety of biological activities shown by this plant. Earlier reports of the phytochemical studies on the whole plant of $H$. abyssinica, found from different locations, revealed the presence of cirsiliol, trans 3,5-dihydroxy-4,7-dimethoxydihydroflavonol, vanillin, protocatechuic acid, catechin, stigmasterol, oleic acid, myristic acid and palmitric acid [17]. While, catechin, tyrosol and ethyl 3,4,-dihydroxybenzoate, were only isolated from the roots [25]. Our studies led to the isolation of salidroside for the first time from this plant.

Several other phytochemical studies on the roots of $N$. mitis have resulted in the isolation of neorautanone, 4methoxyneoduline [14] 12a-hydroxyerosone, iseoliptol 
Table 2 Inhibitory activities of crude extracts and isolated compounds against $P$. falciparum, T. brucei rhodesiense, and $M$. tuberculosis

\begin{tabular}{|c|c|c|c|c|}
\hline \multirow{2}{*}{$\begin{array}{l}\text { Compounds } \\
(\mu \mathrm{M}) \\
\text { Crude Extracts } \\
\text { ( } \mu \mathrm{g} / \mathrm{mL})\end{array}$} & \multirow{2}{*}{$\begin{array}{l}\text { MTB } \\
\text { H37Rv } \\
\text { (MIC } \\
\mu \mathrm{M})\end{array}$} & \multirow{2}{*}{$\begin{array}{l}\text { T. br }\left(I C_{50}\right. \\
\mu \mathrm{M})\end{array}$} & \multicolumn{2}{|l|}{ P. $f\left(\mathrm{IC}_{50} \mu \mathrm{M}\right)$} \\
\hline & & & TM4/8.2 & K1CB1 \\
\hline ABDCM & $>20$ & $3.04 \pm 0.27$ & $\begin{array}{l}2.99 \pm 0.59 \\
S R-0.9\end{array}$ & $\begin{array}{l}2.67 \pm 1.05 \\
S R-1.01\end{array}$ \\
\hline $\mathrm{KEOH}$ & $>20$ & $18.14 \pm 1.34$ & $>50$ & $>50$ \\
\hline $\mathrm{CEOH}$ & $>20$ & $22.89 \pm 1.29$ & $>50$ & $>50$ \\
\hline 1 & $>20$ & $\begin{array}{l}8.74 \pm 0.49 \\
S R-3.3\end{array}$ & $>50$ & $>50$ \\
\hline 2 & $>20$ & $\begin{array}{l}8.91 \pm 0.03 \\
S R-4.52\end{array}$ & $>50$ & $>50$ \\
\hline 3 & $>20$ & $>100$ & $>100$ & $>100$ \\
\hline 4 & $>20$ & $>100$ & $>100$ & $>100$ \\
\hline 5 & $>62.1$ & - & $>31.0$ & $>31.0$ \\
\hline 6 & $>64.9$ & - & $>32.5$ & $>32.5$ \\
\hline 7 & $>34.4$ & - & $>17.2$ & $>17.2$ \\
\hline 10 & $>64.7$ & - & $>32.3$ & $>32.3$ \\
\hline 11 & $>62.0$ & $17.01 \pm 1.83$ & $>31.0$ & $>31.0$ \\
\hline 13 & $>56.9$ & - & $>28.5$ & $>28.5$ \\
\hline 14 & $>59.9$ & $18.65 \pm 3.20$ & $>29.6$ & $>29.6$ \\
\hline 15 & $>56.8$ & $\begin{array}{l}4.87 \pm 0.49 \\
S R>5.83\end{array}$ & $>28.4$ & $>28.4$ \\
\hline 16 & $>56.4$ & - & $>28.2$ & $>28.2$ \\
\hline 19 & $>56.8$ & - & $>28.4$ & $>28.4$ \\
\hline 20 & $>52.3$ & $7.51 \pm 0.17$ & $>26.2$ & $>26.2$ \\
\hline 21 & $>55.2$ & $8.63 \pm 1.14$ & $>27.6$ & $>27.6$ \\
\hline 22 & $>61.7$ & - & $>30.9$ & $>30.9$ \\
\hline 24 & $>20$ & $23.54 \pm 1.59$ & $\begin{array}{l}0.40 \pm 0.07 \\
S R-108\end{array}$ & $\begin{array}{l}0.74 \pm 0.29 \\
S R-133\end{array}$ \\
\hline Isoniazid & 0.02 & - & - & - \\
\hline Rifampin & 0.08 & - & - & - \\
\hline Cycloguanil & - & - & $0.076 \pm 0.016$ & $10.7 \pm 1.62$ \\
\hline Pyrimethamine & - & & $0.095 \pm 0.02$ & $23.21 \pm 2.24$ \\
\hline Pentamidine & - & $0.007 \pm 0.00004$ & - & - \\
\hline
\end{tabular}

Abbreviations: MTB Mycobacterium tuberculosis, T. br Trypanosoma brucei rhodesience, $P$. f Plasmodium falciparum, SR Safety ratio

[15], neoraudiol [16], together with neodulin (6), pachyrrhizine (10), neotenone (11), 12a-hydroxydolineon (13), dolineon (14), rotenone (20), 12a-hydroxyrotenone (21), dehydroneotenone (22) [11, 14-16], nepseudin (16) [62], rautandiol A (23) and rautandiol B (24) [15]. Our earlier studies led to the isolation of one new compound (12) and nine known compounds including compounds 5, 7, $8,9,12,15,17,18$ and 19 , which were isolated for the first time from $N$. mitis [11].
P. falciparum, T. brucei rhodesiense, and M. tuberculosis, are causative agents for malaria, trypanosomiasis and tuberculosis, respectively. These diseases are considered as re-emerging and their reoccurrence is either as a result of a breakdown in public health measures, the appearance of new strains of the causative organism or drug resistance [40,41]. Due to the importance of this trend, it has become essential to invest in the alternative treatment to combat this reemergence, and this can be achieved through the continuous search for new drug leads from natural sources. The screening of ABDCM showed significant inhibitory activity against $P$. falciparum and T. brucei rhodesiense, however, low safety ratios (SR) were observed in both strains of P. falciparum (TM4/8.2 and $\mathrm{K} 1 \mathrm{CB} 1$ ) and this can be attributed to the earlier reports which suggested that the cytotoxicity of ABDCM may be caused by compounds 20 and $\mathbf{2 1}$, as they were both cytotoxic $[11,15]$. The significant inhibitory activity of compound $\mathbf{2 4}$ against the two strains of $P$. falciparum can account for the same activity showed by the ABDCM extract from which it was isolated. This demonstrates its potential as an antimalarial agent due to its activity against the mosquito vector and its larva $[6,12]$. Importantly compound 24 was reported as non-cytotoxic on VERO and BHK21 cells [11]. With this safety range and excellent activity, compound $\mathbf{2 4}$ can be considered as a potential lead candidate for the development of a new anti-malaria drug.

ABDCM also showed significant inhibitory activity against $T$. brucei rhodesiense, compounds 11, 14, 15, 20 and 21 are thought to be responsible for this activity, compound $\mathbf{1 5}$ gave the highest inhibitory activity and can serve as a lead candidate in the development of new therapy for trypanosomiasis. The inhibitory activity of ABDCM and its compounds against very important heamo-parasites like P. falciparum and T. brucei rhodesiense gives a lead for further investigations against other hemooparasites. Compounds 1 and $\mathbf{2}$ also gave moderate inhibitory activity against $T$. brucei rhodesiense and could be responsible for the same inhibitory activity shown by $\mathrm{CEOH}$, from which these compounds were isolated. The inhibitory activities of the ABDCM and $\mathrm{CEOH}$ extracts against $T$. brucei rhodesiense are reported here for the first time based on our literature search.

All of the crude extracts from the selected plants except $A B A Q$, showed significant inhibitory activities against AG and AA, indicating their potential usefulness in the treatment of type II diabetes, which is a condition in which the capacity of the body to produce sufficient insulin is gradually lost. It is a 


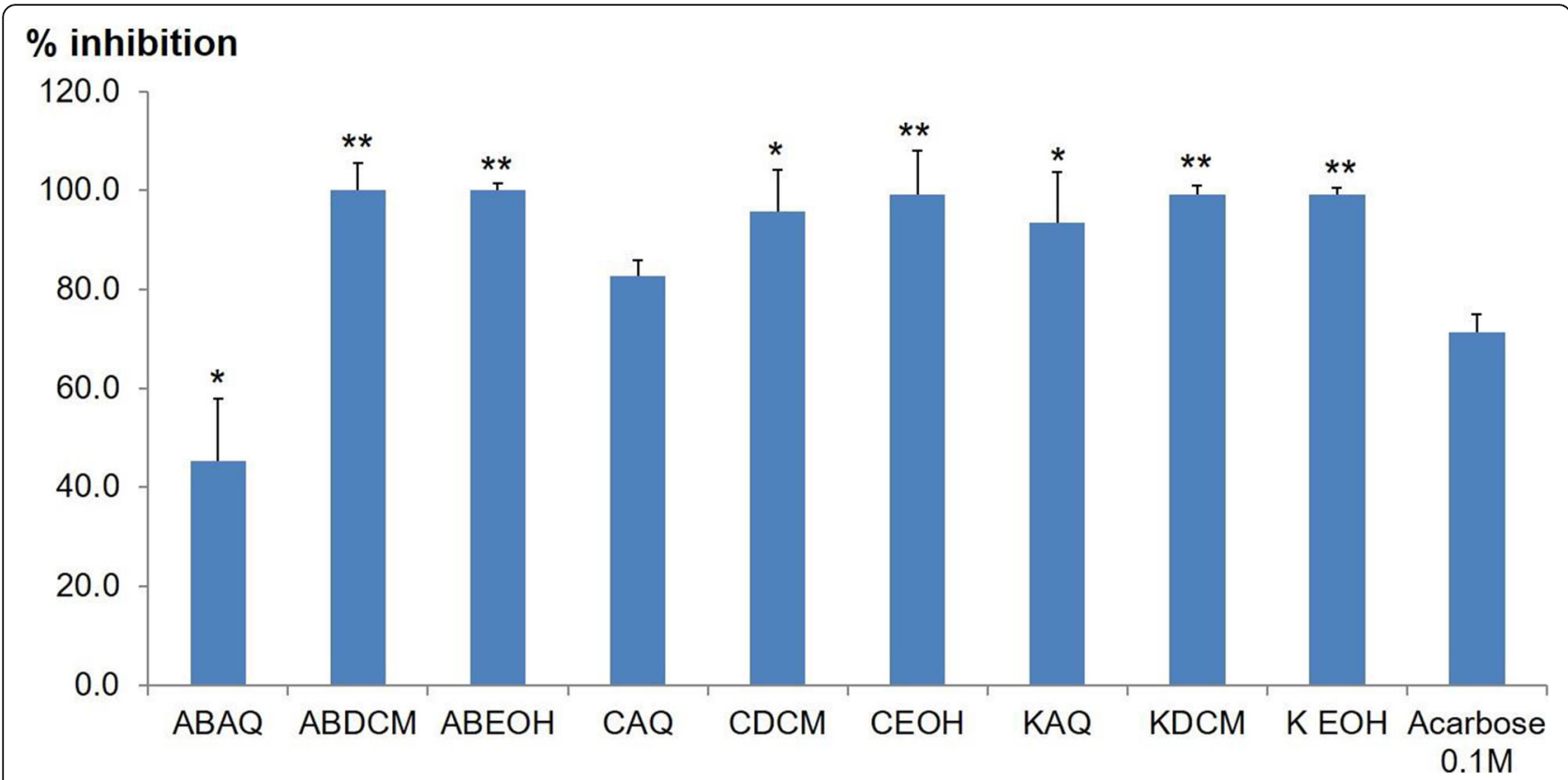

Fig. $3 \mathrm{AGl}$ activities of crude extracts at $500 \mu \mathrm{g} / \mathrm{mL}$. Data are expressed as the mean $\pm \mathrm{SD}$. ANOVA analysis was performed in multiple comparisons to Acarbose $0.1 \mathrm{M}$. ${ }^{*} \mathrm{p} \leq 0.05 ;{ }^{* *} p \leq 0.001$

degenerative condition in which the body becomes resistant to the normal effects of insulin, due mainly to excessive glucose absorption from the gastrointestinal tract (GIT) [63, 64]. The ability of the extracts to inhibit the digestive enzymes (AG and AA), which are responsible for the breakdown of starch or disaccharides and making glucose available for uptake by the small intestine, shows they are potential inhibitors of these enzymes which have been targeted in the effective management of glycaemia and maintaining glucose homeostasis [64-66].

The root crude extract of $H$. abyssinica was reported for its antioxidant and antiglycation activities, and these activities are also thought to be helpful in the management of diabetes complications [17]. The ethanol crude extract of $S$. surrattensis was previously screened for antidiabetic activity [37]. Both KEOH and $\mathrm{CEOH}$ showed significant inhibitory activity against AA and AG. Catechin (3) was isolated from both extracts and it is thought to be partly responsible for this activity. Catechin (3) is known for its bioactivities and health benefits, studies have revealed its ability to treat the symptoms of diabetes and its complications through the modification of oxidative stress $[64,65]$. The observed modest inhibitory

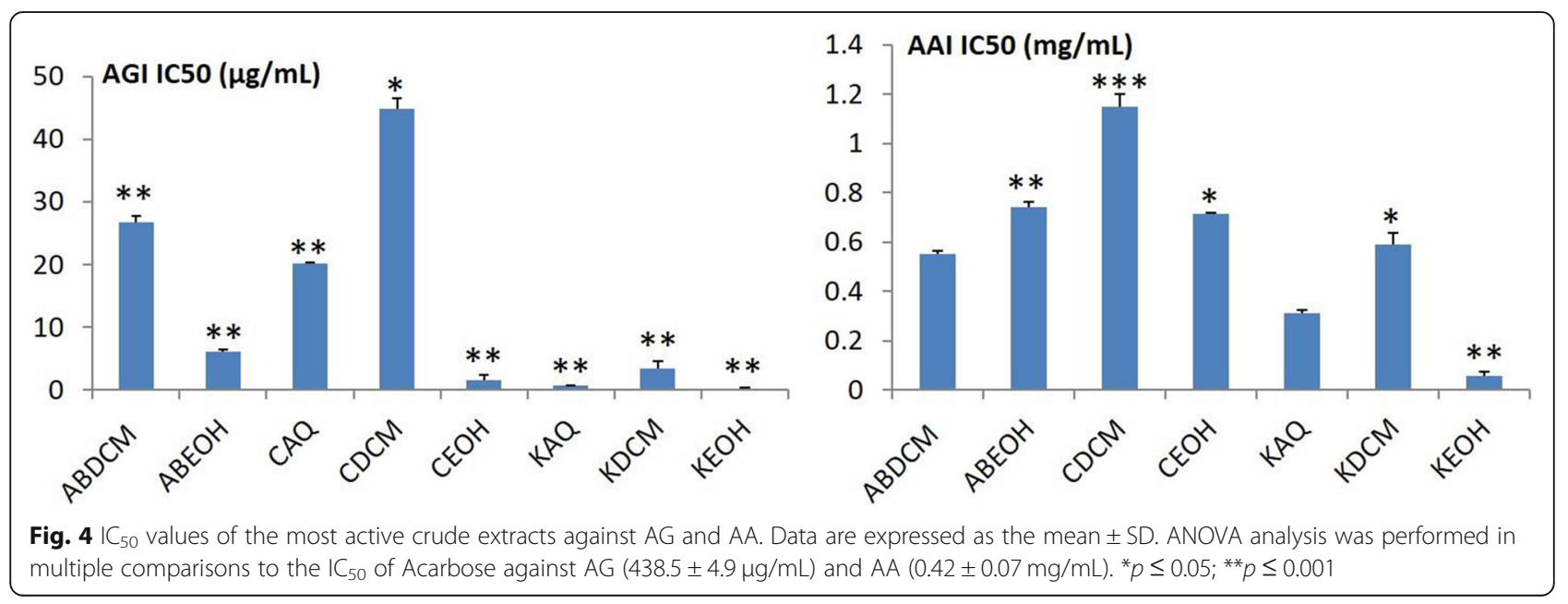


Table 3 Screening of compounds for AGl activity

\begin{tabular}{ll}
\hline Samples $(\mathbf{2 5 0} \boldsymbol{\mu g} / \mathbf{m L})$ in $\mathbf{5 0}$ DMSO & \% Inhibition \\
\hline $\mathbf{3}$ & $97.5 \pm 0.6$ \\
$\mathbf{4}$ & $47.7 \pm 1.8$ \\
$\mathbf{7}$ & $14.8 \pm 0.8$ \\
$\mathbf{1 2}$ & $17.7 \pm 0.3$ \\
$\mathbf{1 4}$ & $54.2 \pm 8.9$ \\
$\mathbf{1 5}$ & $31.5 \pm 2.1$ \\
$\mathbf{2 1}$ & $19.9 \pm 11.4$ \\
$\mathbf{2 3}$ & $83.9 \pm 1.0$ \\
$\mathbf{2 4}$ & $29.3 \pm 3.1$ \\
Acarbose $\mathbf{0 . 1} \mathbf{M}$ & $86.5 \pm 0.4$ \\
DMSO 50\% & 0 \\
\hline
\end{tabular}

activities of the individual isolated phytochemicals indicate that other compounds or synergistic effects between the phytochemical components in these crude extracts may be responsible for the observed inhibitory activities against AG and AA.

\section{Conclusion}

The extracts from the three selected medicinal plants have shown significant inhibitory activities against $P$. falciparum, T. brucei rhodesiense, $\alpha$-amylase (AA) and $\alpha$ glucosidase (AG). This study has revealed some of the individual compounds responsible for these inhibitory activities, giving indications for possible lead compounds for the development of new therapies against diseases caused by these agents. The inhibitory activity of the $N$. mitis compound 24 (rautandiol B) against $P$. falciparum was identified for the first time. It was found to be relatively safe based on its high safety ratio and therefore further studies on this compound are highly recommended for the development of alternative antimalarial therapy. Our study also revealed the importance of screening already identified and useful medicinal plants, as an aid in the discovery of new bioactivities which may be useful in the future development of new alternative therapeutic drugs.

Table $4 I_{50}$ values of the most active compounds against aglucosidase (AG) and a-amylase (AA)

\begin{tabular}{lll}
\hline Compounds in 50\% DMSO & $\begin{array}{l}\text { AG } \\
\text { IC }_{\mathbf{5 0}}(\mathbf{m M})\end{array}$ & $\begin{array}{l}\text { AA } \\
\text { IC }_{\mathbf{5 0}}(\mathbf{m M})\end{array}$ \\
\hline $\mathbf{3}$ & 0.36 & 2.26 \\
$\mathbf{4}$ & 1.38 & $\mathrm{ND}$ \\
$\mathbf{1 4}$ & 0.66 & $\mathrm{ND}$ \\
$\mathbf{2 3}$ & 0.28 & $\mathrm{ND}$ \\
Acarbose & 0.91 & 0.68 \\
\hline
\end{tabular}

ND Not determined

\section{Abbreviations}

MTB: Mycobacterium tuberculosis; Tbr: Trypanosomea brucei rhodesiense; MIC: Minimum concentration that causes 100\% growth inhibition; $I_{50}$ : Concentration that causes 50\% growth inhibitory; HEPES: (4-(2hydroxyethyl)-1-piperazineethanesulfonic acid); DCM: Dichloromethane; $\mathrm{CDCl}_{3}$ : Deuterated chloroform; AA: a-amylase; AG: a-glucosidase; CC: Column chromatography; PTLC: Preparative thin layer chromatography; TLC: Thin layer chromatography

\section{Supplementary Information}

The online version contains supplementary material available at https://doi. org/10.1186/s12906-021-03406-y.

\section{Additional file 1.}

\section{Acknowledgements}

The authors wish to acknowledge the University of Wollongong and the University of Jos for the financial support towards this research. The authors wish to acknowledge Dr. Wilford Lie for his help with obtaining some of the NMR data. Mr. Yilnya Gosomji and other TM practitioners are acknowledged for sharing their valuable traditional knowledge.

\section{Authors' contributions}

CJD and SGP conceived and designed all the experiments, carried out isolation and identification of compounds, drafted and reviewed the manuscript. SK and PTMN designed the experiments, carried out bioactivity evaluation, and drafted/reviewed the manuscript. MTHN, JP, KD, RB and RR carried out the bioactivity evaluation and reviewed the manuscript. All the authors have read and approved the manuscript.

\section{Funding}

University of Jos and University of Wollongong provided a PhD scholarship for this project, SK was supported by a Research Chair Grant (project no. P1850116) from the National Science and Technology Development Agency (NSTDA), Thailand. These funding however, have not played any role directly or indirectly to influence the design, data collection, and results of this study.

Availability of data and materials

The datasets used during the current study are available from the corresponding author on reasonable request.

\section{Declarations}

Ethics approval and consent to participate Not applicable.

\section{Consent for publication}

Not applicable.

\section{Competing interests}

The authors declare they have no any conflicts of interest.

\section{Author details}

${ }^{1}$ School of Chemistry and Molecular Bioscience, Faculty of Science Medicine and Health, University of Wollongong, Wollongong, NSW 2522, Australia. ${ }^{2}$ Department of Veterinary Physiology, Biochemistry and Pharmacology University of Jos, Jos Plateau State, Nigeria. ${ }^{3}$ Department of Life Science, University of Science and Technology of Hanoi, Vietnam Academy of Science and Technology, 18 Hoang Quoc Viet, Cau Giay, Hanoi, Vietnam. ${ }^{4}$ National Center for Genetic Engineering and Biotechnology, National Science and Technology Development Agency, Pathum Thani 12120, Thailand.

${ }^{5}$ Department of Plant Biochemistry, Institute of Biotechnology, Vietnam Academy of Science and Technology, 18 Hoang Quoc Viet, Cau Giay, Hannoi, Vietnam. 
Received: 10 November 2020 Accepted: 2 September 2021

\section{Published online: 13 September 2021}

\section{References}

1. Boadu AA, Asase A. Documentation of herbal medicines used for the treatment and management of human diseases by some communities in southern Ghana. Evid Based Complement Alternat Med. 2017;3043061:1-12.

2. Offiah NV, Makama S, Elisha IL, Makoshi MS, Gotep JG, Dawurung CJ, et al. Ethnobotanical survey of medicinal plants used in the treatment of animal diarrhea in Plateau State, Nigeria. BMC Vet Res. 2011;7(1):36-45. https://doi. org/10.1186/1746-6148-7-36.

3. Dawurung CJ, Jurbe GG, Usman JG, Elisha IL, Lombin LH, Pyne SG. Antidiarrheal activity of some selected Nigerian plants used in traditional medicine. Phcog Res. 2019;11(4):371-7. https://doi.org/10.4103/pr.pr_43_19.

4. Zhou X, Seto SW, Chang D, Kiat H, Razmovski-Naumovski V, Chan K, et al. Synergistic effects of Chinese herbal medicine: a comprehensive review of methodology and current research. Front Pharmacol. 2016;7:201. https://doi. org/10.3389/fphar.2016.00201.

5. Vickers A, Zollman C, Lee R. Herbal medicine. West J Med. 2001;2(2):125-8. https://doi.org/10.1136/ewjm.175.2.125.

6. Joseph JM, Erasto P. Bioactive natural products derived from the east African flora. Nat Prod Rep. 2009;26(12):1535-54. https://doi.org/10.1039/ b906089h.

7. Van Duuren BL. Chemistry of edulin, Neorautone, and related compounds from Neorautanenia edulis C.A. Sm. J Org Chem. 1961;12:5013-20.

8. Breytenbach JC, Rall GJH. Structure and synthesis of isoflavonoid analogues from Neorautanenia amboensis Schinz. J Chem Soc Perkin Trans. 1980;0: 1804-9. https://doi.org/10.1039/p19800001804.

9. Vongtau HO, Amos S, Binda L, Kapu SD, Gamaniel KS, Kunle OF, et al. Pharmacological effects of the aqueous extract of Neorautanenia mitis in rodents. J Ethnopharmacol. 2000;72(1-2):207-14. https://doi.org/10.1016/S03 78-8741(00)00247-6.

10. Heyndrickx G, Briven P, Puyvelde LV. Study of Rwandese medicinal plants used in the treatment of scabies. J Ethnopharmacol. 1992;35(3):259-62. https://doi.org/10.1016/0378-8741(92)90022-J.

11. Dawurung CJ, Noitem R, Rattanajak A, Bunyong R, Richardson C, Willis CA, et al. Isolation of CFTR and TMEM16A inhibitors from Neorautanenia mitis (A. Rich) Verdcourt: potential lead compounds for treatment of secretory diarrhea. Phytochemistry. 2020;179:112464. https://doi.org/10.1016/j. phytochem.2020.112464.

12. Puyvelde LV, Norbert D, Kimpe ND, Jean-Pierre JP, Mudaheranwa A, Gasiga NS, et al. Isolation and structure elucidation of potentially insecticidal and acaricidal isoflovone- type compounds from Neorautanenia mitis. J Nat Prod. 1987;50(3):349-56. https://doi.org/10.1021/np50051a002.

13. Vongtau HO, Abbah J, Mosugu O, Chindo BA, Ngazal IE, Salawu AO, et al. Antinociceptive profile of the methanolic extract of Neorautanenia mitis root in rats and mice. J Ethnopharmacol. 2004;92(2-3):317-24. https://doi. org/10.1016/j.jep.2004.03.014.

14. Joseph CC, Ndoile MM, Malima RC, Nkunya MHH. Larvicidal and mosquitocidal extracts, a coumarin, isoflavonoids and pterocarpans from Neorautanenia mitis. Trans R Soc Trop Med Hyg. 2004;98(8):451-5. https:// doi.org/10.1016/j.trstmh.2003.10.008.

15. Sakurai $Y$, Sakurai N, Masahiko T, Nakanishi $Y$, Bastow KF, Wang X, et al. Rautandiols $A$ and $B$, pterocarpans and cytotoxic constituents from Neorautanenia mitis. J Nat Prod. 2006;69:397-9.

16. Lasisi AA, Adesomoju A. Neoraudiol, a new isoflavonoid and other antimicrobial constituents from the tuberous root of Neorautanenia mitis (A. Rich) Verdcourt. J Saudi Chem Soc. 2015;19:404-9.

17. Yagi $S$, Chrétien F, Duval RE, Fontanay S, Maldini M, Piacente $S$, et al. Antibacterial activity, cytotoxicity and chemical constituents of Hydnora johannis roots. S Afr J Bot. 2012;78:228-34. https://doi.org/10.1016/j.sajb.2 011.09.010.

18. Dold T, Cocks M. Fine fare, rare remedy. Veld Flora. 2003;89:12-4.

19. Williams VL, Falcao MP, Wojtasik EM. Hydnora abyssinica: ethnobotanical evidence for its occurrence in southern Mozambique. S Afr J Bot. 2011;2(2): 474-8. https://doi.org/10.1016/j.sajb.2010.09.010.

20. Botha J, Witkowski ETF, Shackleton CM. An inventory of medicinal plants traded on the western boundary of the Kruger National Park, South Africa. Koedoe. 2001;44(2):7-4. https://doi.org/10.4102/koedoe.v44i2.172.

21. Barbosa F, Hlashwayo D, Sevasyanov V, Chichava V, Mataveia A, Boane E, et al. Medicinal plants sold for the treatment bacterial and parasitic disease in humans in Maputo city markets, Mozambique. BMC Complement Alternat Med. 2020;19:1-13.

22. Mkala EM, Mutungi MM, Mutinda ES, Oulo MA, Wanga VO, Mwachala G, et al. Understanding the ethnobotany, chemistry, pharmacology, and distribution of genus Hydnora (Aristolochiaceae). Plants. 2021;10(3). https:// doi.org/10.3390/plants10030494.

23. Wintola OA, Afolayan AJ. Chemical constituents and biological activities of essential oils of Hydnora africana Thumb used to treat associated infections and diseases in South Africa. Appl Sci. 2017;7(5):443. https://doi.org/10.33 90/app7050443.

24. Al-Fatimi M, Ali N, Kilian N, Franke K, Arnold N, Kuhnt C, et al. Ethnobotany, chemical constituents and biological activities of the flowers of Hydnora abyssinica A. Br. (Hydnoraceae). Pharmazie. 2016;71(4):222-6.

25. Koko WS, Mesaik MA, Ranjitt R, Galal M, Choudhary MI. Immunosuppressive phenolic compounds from Hydnora abyssinica A. Braun. BMC Complement Alternat Med. 2015;15(1):400. https://doi.org/1 0.1186/s12906-015-0931-x

26. Issa TO, Mohamed YS, Yagi S, Ahmed RH, Najeeb TM, Makhawi AM, et al. Ethnobotanical investigation on medicinal plants in Algoz area (South Kordofan), Sudan. J Ethnobiol Ethnomed. 2018;14(1):31. https://doi.org/10.11 86/s13002-018-0230-y.

27. Musselman LJ, Visser $\mathrm{JH}$. Taxonomy and natural history of Hydnora (Hydnoraceae). Aliso. 1989;12(2):317-26. https://doi.org/10.5642/aliso.198912 02.09

28. Onyanchi JM, Cherongis CN, Nzivo JM, Muriithi GI, Njuguna DG, Mwalukumbi JM. Phytochmical screening and evaluation of antioxidant activity of methanolic extract of Kenyan Hydnora abyssinica A. Braun (Hydnoraceae). JIPBS. 2015;1:1-6.

29. Ayoub SMH, Yankov L. Potential molluscicides from some tannin-containing plants growing in the Sudan. Fitoterapia. 1985;6:371-3.

30. Sosef MSM, Maesen LJG. Senna surattensis (Burm.) Irwin and Barneby. In: Plant Resources of South-East Asia (PROSEA) auxiliary plants no 11. Leiden: Backhuys Publisher; 1997.

31. Burkill $I \mathrm{H}$. A dictionary of the economic products of the malay peninsula. Kuala Lumpur: Government of Malaysia and Singapore, Ministry of Agriculture and Cooperatives; 1935.

32. Sumathy $V$, Zakaria Z, Chen Y, Latha LY, Jothy SL, Vijayarathna S, et al. Evaluation of the effect of Cassia surattensis Burm. f., flower methanolic extract on the growth and morphology of Aspergillus niger. Eur Rev Med Pharmacol Sci. 2013;17(12):1648-54.

33. Deepak K, Shefali A, Ankit V. Fatty acid composition and antimicrobial and antioxidant activity of Cassia glauca seed extracts. Int J Phytopharmacol. 2013:2:113-8

34. Sangetha S, Sasidharan S, Zuraini Z, Suryani S. Antioxidant activity of methanolic extracts of Cassia surattensis. Pharmacologyonline. 2008;2:82938.

35. Uthaya KUS, Chen Y, Kanwar JR, Sasidharan S. Redox control of antioxidant and antihepatotoxic activities of Cassia surattensis seed extract against paracetamol intoxication in mice: in-vitro and in-vivo studies of herbal green antioxidant. Oxidative Med Cell Longev. 2016;2016:6841348. https://doi. org/10.1155/2016/6841348.

36. Ramesh PR, Vijaya C, Devika GS. Evaluation of anti-diabetic activity of Cassia surattensis Burm flower in streptozotocin induced diabetic rats. Int J Pharm Sci Res. 2012;2:200-5.

37. Thilagam E, Parimaladevi B, Kumarappan C, Mandal SC. a-Glucosidase and a-amylase inhibitory activity of Senna surattensis. J Acupunct Meridian Stud. 2013;1:24-30

38. El-sawi SA, Sleem AA. Flavonoids and hepatoprotective activity of leaves of Senna Surattensis (Burm.f.) in CCl4 induced hepatotoxicity in rats. Aust J Basic App Sci. 2010;6:1326-34.

39. El-sawi SA, Sleem AA. Anthihyperlipidimic, antihyperglycemic and chemical composition of senna surattensis. Can J Pure App Sci. 2009;2:779-85.

40. Muzemil A, Fasanmi OG, Fasina FO. African perspectives: modern complexities of emerging, re-emerging, and endemic zoonoses. J Glob Health. 2018;2(2):020310. https://doi.org/10.7189/jogh.08.020310.

41. Fauci AS. New and re-emerging diseases: the importance of biomedical research. Emerg Infect Dis. 1998;3(3):374-8. https://doi.org/10.3201/eid0403. 980308.

42. WHO World malaria report 2018. Geneva: World Health Organization; 2018. https://www.who.int/malaria/publications/world_malaria_report/en/. Accessed 27 Nov 2019. 
43. Cui L, Mharakurwa S, Ndiaye D, Rathod PK, Rosenthal PJ. Antimalarial drug resistance: literature review and activities and findings of the ICEMR network. Am J Trop Med Hyg. 2015;93(3_Suppl):57-68. https://doi.org/10.42 69/ajtmh.15-0007.

44. Sasidharan S, Chen Y, Sundram KM, Yoga LL. Extraction, isolation and characterization of bioactive compounds from plants extracts. Afr J Tradit Complement Altern Med. 2011:8:1-10.

45. Desjardins RE, Canfield CJ, Haynes JD, Chulay JD. Quantitative assessment of antimalarial activity in vitro by semi-automated microdilution technique Antimicrob. Agents Chemother. 1979;16(6):710-8. https://doi.org/10.1128/AA C.16.6.710.

46. Kamchonwongpaisan S, Quarrell R, Charoensetakul N, Ponsinet R, Vilaivan T, Vanichtanankul J, et al. Inhibitors of multiple mutants of Plasmodium falciparum dihydrofolate reductase and their antimalarial activities. J Med Chem. 2004;47(3):673-80. https://doi.org/10.1021/jm030165t.

47. Wangchuk P, Keller PA, Pyne SG, Taweechotipatr M, Tonsomboon A, Rattanajak $R$, et al. Screening of ethnopharmacologically selected Bhutanese medicinal plants for their phytochemical profiles and biological activities. J Ethnopharmacol. 2011;137(1):730-42. https://doi.org/10.1016/j.jep.2011.06. 032.

48. Cullen DR, Pengon J, Rattanajak R, Chaplin J, Kamchonwongpaisan S, Mocerino M. Scoping studies into the structure-activity relationship (SAR) of phenylephrine-derived analogues as inhibitors of Trypanosoma brucei rhodesiense. ChemistrySelect. 2016;1:4533-8.

49. Collins L, Franzblau SG. Microplate alamar blue assay versus BACTEC 460 system for high-throughput screening of compounds against Mycobacterium tuberculosis and Mycobacterium avium. Antimicrob Agents Chemother. 1997;41(5):1004-9. https://doi.org/10.1128/AAC.41.5.1 004.

50. Nguyen MTT, Nguyen HX, Huynh TNN, Min BS. Screening of a-glucosidase inhibitory activity of Vietnamese medicinal plants: isolation of active principles from Oroxylum indicumin. Nat Prod Sci. 2012;18:47-51.

51. Xiao Z, Storms R, Tsang A. Quantitative starch-iodine method for measuring alpha-amylase and glucoamylase activities. Anal Biochem. 2006;351(1):146-8. https://doi.org/10.1016/j.ab.2006.01.036.

52. Lin LJ, Huang XB, Lv ZC. Isolation and identification of flavonoids components from Pteris vittata L. SpringerPlus. 2016;1(1):1649. https://doi. org/10.1186/s40064-016-3308-9

53. Kashiwada Y, lizuka H, Yoshioka K, Chen R, Nonaka G, Nishioka I. Tannins and related compounds. XCIII. Occurrence of enantiomeric proanthocyanidins in the Leguminosae plants, Cassia fistulan L. and Cassia javanica L. Chem Pharm Bull. 1990;4:888-93.

54. Shi T, Chen H, Jing L, Liu X, Sun X, Jiang R. Development of a kilogram-scale synthesis of salidroside and its analogs. Synth Commun. 2011;177(17):2594600. https://doi.org/10.1080/00397911.2010.515332.

55. Truong D, Nguyen DH, Ta NTA, Bui AV, Do TH, Nguyen HC. Evaluation of the use of different solvents for phytochemical constituents, antioxidants, and in vitro anti-inflammatory activities of Severinia buxifolia. J Food Qual. 2019;8178294:1-9. https://doi.org/10.1155/2019/8178294.

56. Rai KN, Kaushalendra K, Singh J. Chemical constituents from the pods of Cassia glauca Lam. Asian J Chem. 1997;1:44-9.

57. Tiwari HP, Misra M. Phytochemical investigation of Cassia glauca bark. J Ind Chem Soc. 1993;7:653

58. Rai KN, Roy RA. A new anthraquinone glycoside from the stem of Cassia glauca, Lam. J Bangladesh Acad Sci. 1991;2:193-8.

59. Hemlata S, Kalidhar SB. Chemical components of Cassia glauca Lam. Ind J Pharma Sci. 1994;1:33-4.

60. Salpekar J, Khan SA. Luteolin-7-O- $\beta-D-g l u c o p y r a n o s y l-(1-4)-O-\beta-L-$ arabinopyranoside from Cassia glauca. Ult Scientist Phys Sci. 1996;2:260-1.

61. Khare GC, Dixit AK, Gupta PC. Phytochemical investigation of the Cassia glauca seeds. Nat Acad Sci Lett. 1994;2:21-3.

62. Crombie L, Whiting DA. The extractives of Neorautanenia pseudopachyrrhiza the isolation and structure of a new rotenoid and two isoflavanones. J Chem Soc. 1963:1569-79. https://doi.org/10.1039/jr9630001569.

63. Bhandari MR, Jong-Anurakkun N, Hong G, Kawabata J. a-Glucosidase and aamylase inhibitory effects of Nepalese medicinal herb Pakhanbhed (Bergenia ciliata, Haw.). Food Chem. 2008;106(1):247-52. https://doi.org/10.1016/j. foodchem.2007.05.077.

64. Kim YM, Jeong YK, Wang MH, Lee WY, Rhee HI. Inhibitory effect of pine extract on a-glucosidase activity and postprandial hyperglycemia. Nutrition. 2005;21(6):756e761. https://doi.org/10.1016/j.nut.2004.10.014.
65. Krentz AJ, Bailey C. Oral antidiabetic agents: current role in type 2 diabetes mellitus. Drugs. 2005;65(3):385-411. https://doi.org/10.2165/00003495-2 00565030-00005.

66. Blonde L. Benefits and risks for intensive glycemic control in patients with diabetes mellitus. Am J Med Sci. 2012;343(1):17-20. https://doi.org/10.1097/ MAJ.0b013e31823ea23e

\section{Publisher's Note}

Springer Nature remains neutral with regard to jurisdictional claims in published maps and institutional affiliations.
Ready to submit your research? Choose BMC and benefit from:

- fast, convenient online submission

- thorough peer review by experienced researchers in your field

- rapid publication on acceptance

- support for research data, including large and complex data types

- gold Open Access which fosters wider collaboration and increased citations

- maximum visibility for your research: over $100 \mathrm{M}$ website views per year

At $\mathrm{BMC}$, research is always in progress.

Learn more biomedcentral.com/submissions 